\title{
3.2 Підприємницька діяльність в аграрному секторі
}

Дослідження сутності категорії підприємницька діяльність завжди було полемічним питанням як в економічній теорії так і в економіці в цілому, його важливість визнають майже всі вчені, які працюють над такими дослідженнями. Як історично обумовлене явище, підприємницька діяльність проявляється через систему відносин у різних сферах життєдіяльності суспільства: на макрорівні як чинник суспільного виробництва та рушійна сила науково-технічного прогресу; на мікрорівні - як специфічна поведінкова стратегія взаємовідносин 3 учасниками ринку[63]. В понятійному плані підприємництво постійно еволюціонує, воно носить міждисциплінарний та метанауковий характер. Нормативне регулювання підприємницької діяльності викладено в Господарському кодексі України[64].

Водночас, уявлення про мету підприємницької діяльності тільки як про одержання прибутку, на думку Корольова В.І., веде до ототожнення підприємництва зі звичайним бізнесом [65]. Звичайно, бізнес і підприємництво мають багато загального. Їх характеризує самостійність, відповідальність, ризик, ініціатива. Однак, підприємництво характеризується ще і рядом специфічних рис, таких як: новаторство, творчий пошук рішень, комбінування різних факторів виробництва, одержання доходу внаслідок кращого використання факторів виробництва, тощо. Проте, деякі вчені поняття бізнесу та підприємництва не уточнюють і не завжди проводять між ними межу та не дають чіткого визначення відповідних понять. Однак твердження про рівнозначність понять «підприємництво» i «бізнес», на нашу думку, є недоцільним. А. Гальчинський визначає бізнес як більш широке поняття, ніж підприємництво, останнє є окремим випадком бізнесу [66]. Проведені дослідження свідчать, що для двох близьких понять «бізнес» і «підприємництв

Для кращого розуміння сутності підприємницької діяльності розглянемо еволюцію даного поняття в зарубіжній та вітчизняній літературі. У буржуазній політекономії поняття підприємництва з'явилось ще у ХІІІ ст. у Франції. Ранні 
теорії підприємництва базуються на роботах Й. Шумпетера та І. Кірцнера. Проте, сучасний еволюційний підхід включає в себе також деякі специфічні теорії, такі як теорія людського капіталу Шлютца, теорія соціальних мереж Грановеттера , теорія нео-Шумпетерської економіки. Першим вченим, який почав досліджувати роль підприємця в економіці був англійський вчений Р. Кантільйон? який класифікував економічних агентів на три групи: землевласники, підприємці та наймана робоча сила. В праці «Essai sur la nature du commerce en g'en'eral» $\mathrm{P}$. Кантільйон характеризував першу та третю групу як пасивних агентів, тоді як підприємцям відвів активну роль в економічній системі [67]. Відповідно до його концепції підприємці є координаторами, ланкою, яка з'єднує виробника із споживачем. При цьому він наголошував, що підприємець не завжди має бути власником капіталу. Великий внесок в дослідження підприємницької діяльності вніс А. Сміт, який визначав підприємця як власника капіталу, ціль діяльності якого - отримання підприємницького прибутку, який є компенсацією власника за ризик [68]. Таким чином, А. Сміт трактував підприємця як власника, пов'язував підприємницьку діяльність передусім із власним інтересом (особистим збагаченням), у процесі реалізації якого підприємець сприяє найефективнішому задоволенню потреб суспільства.

Іншою, скоріше капіталістичною точкою зору є теорія Ж. Тургота, згідно якої підприємець є результатом капіталістичного інвестиційного рішення. Так, власник капіталу може просто позичити свої гроші та бути капіталістом, або придбати земельну ділянку та стати землевласником, або придбати товари та вступити в бізнес, автоматично перетворившись в підприємця [69].

Варто зазначити, що більшість економістів до появи теорії Шумпетера працювали лише над теорією рівноваги. Концепція підприємництва Шумпетера стала відправною точкою для сучасних досліджень підприємництва. Всі теорії підприємництва, які з'явились після виходу в світ праці Шумпетера, базуються саме на його ідеях. До нього, ніхто не виділяв особливу, самостійну роль підприємця як одного з стимулюючих факторів економічного розвитку. Ним вперше була запропонована також послідовна теорія підприємництва. Таким 
чином, сучасне уявлення про підприємця та його ролі в господарській діяльності в значній мірі базується на концепції Й. Шумпетера. Цей видатний вчений в контексті підприємництва приділяв увагу інноваціям, він вважав, що це не тільки виготовлення нових продуктів та введення нових технологій, але й освоєння нових ринків збуту, джерел сировини, форм індустріальної організації. Підприємницька діяльність, за Шумпетером, - це не посада і не фах, а, скоріше, унікальна і рідкісна На його думку підприємницька функція полягає в реалізації організаційно-господарських нововведень, які відіграють головну роль в розвитку економіки, забезпечуючи іiі зростання. Тобто, підприємець-інноватор визнається однією з центральних фігур господарської діяльності. Водночас, підприємницьку функцію можуть виконувати як одна особа, так і група осіб. Основна мета підприємницької діяльності - це прибуток, і він важливий як критерій успіху, як оцінка якості реалізованого проекту. Окрім того Й. Шумпетер виділяє такі цілі як: потреба в пануванні, влади, впливі; радість творчості, яку дає самостійне ведення справ. Він не вважав важливою характеристикою підприємництва право власності на підприємство чи інше майно, навпаки, належність до конкретного підприємства він вважав навіть шкідливою для реалізації підприємницької функції. Також Шумпетер не надавав важливого значення функції несення ризик.

Представники неоавстрійської школи заснували новий напрямок в теорії підприємництва. Поведінка підприємця, залишаючись повністю раціональною, змінюється: це той, хто знаходить нові цілі та нові засоби, наявність яких ніким раніше не помічалися. Заслуговує на увагу висновок Ф. Хаєка про роль середовища, в якому діє підприємець. Незважаючи на наявність жорсткої ринкової конкуренції доля приватних осіб, які мають бажання випробувати нові можливості кругом практично однакова [71]. Сучасні західні економісти підприємницьку діяльність в першу чергу тісно пов’язують 3 інноваційним розвитком. Так, зокрема, Долан Е.Дж. та Ліндсей Д. підприємницьку діяльністю розглядають як процес пошуку нових можливостей, технологій та сфер вкладання капіталу, подолання старих стереотипів та меж [72]. 
Діяльність переважної більшості підприємців у розвинутих країнах підпорядковані дії основного економічного закону (виробництву і привласненню максимальної додаткової вартості у формі прибутку), тому інші виконувані ними функції (новаторська, організаційна, господарська, соціальна та особистісна) підпорядковані цій стратегічній меті. Виходячи із сутності підприємництва (новаторська, організуюча та ін.), попит на підприємців буде зростати, оскільки тенденції сучасного розвитку суспільства потребує породження нових, ефективних та раціональних способів організації використання дефіцитних та зникаючих ресурсів для більш повного задоволення кількісних та якісних потреб людства. Водночас, між підприємництвом та суспільством повинен бути встановлений прямий зв'язок. Амігуд М. та Ройтер А. зазначають в своїй статті, що життєздатність різних підприємницьких структур залежить від того, наскільки успішно вони виконують свою роль локомотиву економічного розвитку, а добробут суспільства прямо залежить від режиму сприяння бізнесу, від існування прибуткових та відповідальних суб'єктів господарювання підприємців. [73]. Таким чином, західна економічна наука дає нам уявлення про підприємництво як специфічну функцію, яка здійснюються не обов'язково власником капіталу, а й менеджером або структурним підрозділом фірми, як самостійна інноваційна діяльність, пов'язана 3 ризиком, спрямована на одержання підприємницького прибутку та яка забезпечує задоволення від досягнутого успіху, повноцінну реалізацію індивідуума, що можлива лише у відповідних соціально-економічних та правових умовах.

Проаналізувавши трактування підприємництва в західній науці, не можна не зупинитися на визначеннях даної категорії у працях вітчизняних науковців. Особистість ділової людини, мотивація його діяльності, роль в економічному житті суспільства значною мірою займали українську наукову думку на рубежі XIX - XX віків. Підтвердженням цього $\epsilon$, зокрема, роботи відомого економіста М. Туган-Барановского, що бачив у підприємці людину, яка працює заради високого прибутку і при цьому розумно ризикує. Те що історія вітчизняної теорії підприємництва продовжує залишатися маловивченою сферою не викликає 
сумніву. Це обумовлено тим, що донедавна багато робіт вітчизняних авторів, як дожовтневого періоду, так і перших післяреволюційних років були закриті і недоступні для українських вчених. Таким чином, специфіка сучасних досліджень в області підприємництва в Україні багато в чому визначається їхньою відірваністю від власних теоретичних джерел, а також припиненням традицій підприємництва.

Як зазначає професор Вороніна Л.І. підприємництвом вважається не будьяка діяльність виробника, банкіра, робітника торгівлі, сфери послуг, а лише діяльність власника, який самостійно (або із залученням найманої робочої сили) розпочинає і здійснює виробництво, надання послуг, торгівлю тощо [74]. За визначенням С. Мочерного, підприємництво є самостійним організаційногосподарським новаторством на основі використання різних можливостей для випуску нових або старих товарів новими методами, відкриття нових джерел сировини, ринків збуту тощо, з метою отримання прибутків і самореалізації власної мети.[75]

На думку Лагутіна В.Д. підприємництво - це ініціативна, пов'язана 3 ризиком, економічна діяльність $з$ ціллю здійснення інновацій і досягнення високого соціально-економічного ефекту розпочатої справи [76]. Динкін А. вважає підприємництво особливим, новаторським, антибюрократичним стилем господарської поведінки, в основі якої покладено постійний пошук сучасних можливостей $з$ орієнтацією на інноваційний розвиток, вміння залучати та долучати для вирішення поставлених завдань ресурси з різних джерел [77]. Кретов С.І. розуміє підприємництво не як прагнення одержати великі доходи, а як спосіб мислення ініціативної людини, що швидко мобілізує наявні в неї ресурси на організацію виробництва в якій-небудь надприбутковій сфері або галузі [78]. Це визначення дає нам уявлення скоріше про особистісні і потенційні можливості індивіда, які проявляються лише при наявності сприятливого економічного середовища. Найбільшого поширення одержало визначення підприємництва як особливого виду діяльності. При цьому слід зазначити, що багато авторів підходять до визначенню цього поняття досить широко. Як 
справедливо відзначає Гордєєва Ю., лідером в діловому світі стає той, у кого є вміння ризикнути та швидко впроваджувати інновації [79]. Професор Ніколенко Ю.В. стверджує, що підприємництво - це певний спосіб життя бізнесу, який базується на демократичних формах економічної діяльності та надає їм право ініціативи у виборі сфери, форм і методів управління, економічної, організаційної та технічної творчості та інновацій. В основі цієї системи лежить підприємець - грамотний менеджер, здатний організувати економіку на основі останніх подій в економіці та технологіях. [80].

Таким чином, при дослідженні суті підприємництва значна увага має приділятися також і характеристиці такого поняття як підприємець, оскільки підприємництво само по собі розуміє конкретну діяльність підприємця, як суб'єкта підприємницької діяльності. Підприємець взаємодіє зі споживачами як основними партнерами, а також з державою, яка може виступати помічником або опонентом у різних ситуаціях. До категорії суб' єктів підприємницької діяльності також потрапляють як споживач (суспільство), так і держава, а також працівник (якщо, звичайно, підприємець працює не один), та ділові партнери (якщо виробництво не відокремлено від суспільних відносин). 3 економічної точки зору, підприємець поєднує засоби виробництва, працю, матеріали, тощо так, що в процесі роботи їх сукупна вартість збільшується. При цьому він вносить певні зміни, здійснює інновації та змінюе установлений порядок на ринку. Підприємець в процесі своєї діяльності, використовуючи нове обладнання та технології у виробничому процесі, організовуючи роботу та виробничі процеси по-новому, отримує вигідний "товар найвищої якості". Надлишок, що генерується в процесі виробництва інноваційного ринку, є підприємницьким доходом. Процес отримання такого прибутку - глибока економічна сутність та суть підприємницької діяльності.

3 точки зору психології, підприємець - це людина, яка діє під впливом певних мотивів, наприклад, бажання досягти успіху в житті, спробувати започаткувати нову справу, самоутвердитися та ін. 3 політекономічної точки зору, підприємець - це людина, яка збільшує не тільки своє, а й національне 
багатство, знаходить способи ефективного використання ресурсів, зменшення збитків, створення робочих місць. Таким чином, підприємець $є$ основним суб' єктом господарювання, який завдяки наявності певної сукупності рис втілює у практику функції підприємництва і за свою працю отримує підприємницький дохід. Внесок підприємця часто розглядають в економічному аналізі фірми як самостійний фактор виробництва. Розбіжність між ним і виробничим ресурсом праці базується на результатах рішень, прийнятих підприємцем. Характер підприємницьких рішень відрізняється у різноманітних формах господарювання сучасних підприємств. Наприклад, в індивідуальних фірмах підприємець одночасно бере на себе фінансовий ризик підприємства i несе виняткову відповідальність за управління ним. У публічних компаніях ці дві функції розподілено між акціонерами, тобто власниками, які несуть фінансовий ризик, $\mathrm{i}$ радою директорів, яка здійснює фактичне керівництво політикою і прийняттям рішень, тобто управлінням фірмою. Часто стверджують, що такий поділ функцій $\epsilon$ джерелом змін ділової поведінки, особливо цілей, які переслідуються фірмою.

В сучасних умовах важливого значення набуває культура підприємницької діяльності в агарній сфері, яка повинна грунтуватися на принципах сталого розвитку.

На думку Лагутіна В.Д., підприємництво включає сукупність різних практичних також матеріальних $\mathrm{i}$ духовних надбань суспільства, які відтворюють досягнутий рівень підприємницької діяльності. У більш вузькому плані під культурою підприємництва розуміють процес обміну інформацією та ідеями, етику ділових відносин [81]. Малик М.Й. виділяє підприємництво як інститут інноваційного розвитку сільського господарства, економічний сектор, який виступає інструментом структурної перебудови, стимулює трансформаційні зміни економічних умов до ринкових. Однак, на думку автора сільськогосподарські підприємства, особливо малі, не стали економічно відповідальними, а надлишок економічної потужності дозволяє диктувати умови формування відносин, які насамперед пов'язані з перерозподілом ренти, а не на користь селянського власника [82]. 
На думку Охоти Ю. В. сільськогосподарське підприємство - це самостійна економічна одиниця, діяльність якої поєднує виробництво, першу переробку та продаж сільськогосподарської продукції. Доцільність подальшого розвитку та підтримки підприємництва в аграрному секторі залишається актуальною. Автор виділяє шляхи розвитку сільськогосподарського підприємництва: поліпшення інституційного середовища для форм малого бізнесу 3 метою створення середнього класу в сільській місцевості та підтримання конкуренції на сільськогосподарському та продовольчому ринках; забезпечення рівного доступу до ресурсів та державної допомоги для всіх бізнес-груп, незалежно від форм власності та розміру; вдосконалення структури сівозміни та впровадження використання органічних добрив у сільському господарстві. товаровиробники; вирішення кадрових проблем за рахунок збільшення кількості висококваліфікованого персоналу; оновлення матеріально-технічної бази; система управління та організація виробничих відносин.[83]. До думки щодо підтримки підприємницької діяльності в аграрному секторі приєднуються такі вчені як Сичова М. О. та Шевченко Н. О. Вони зазаначають, що підприємці потребують підтримки, особливо державної, оскільки навряд чи вони зможуть вирішити всі свої проблеми самостійно та подолати перешкоди, 3 якими стикаються. Але в сучасних умовах держава не зможе повною мірою сприяти розвитку підприємництва, зокрема сільського господарства. Тому підприємцям потрібно пам'ятати про функції підприємництва в суспільстві (ресурсні, організаційні та творчі) та якомога швидше адаптуватися до змін у зовнішньому середовищі, бути більш ініціативними та самостійними у вирішенні своїх проблем, зосереджуючись на забезпеченні ефективного розвитку бізнесу, подолання браку знань про здійснення підприємництва, використання всіх можливих способів залучення інвестицій, вдосконалення структури виробництва, диверсифікація видів підприємництва та інші речі, що є прерогативою самих підприємців.

Розглянувши та узагальнивши теоретико-методологічні підходи до визначення сутності підприємництва в агарному секторі, його функцій та 
соціально-економічного значення, можна зробити висновок, що підприємництво $\epsilon$ необхідною умовою економічного зростання країни, джерелом покращення добробуту пересічних громадян та їх соціальної захищеності.

Підсумовуючи вищенаведене на основі узагальнення результатів дослідження ми розуміємо категорію «підприємництво в аграрній сфері» як інноваційний вид діяльності, заснований на прагненні окремих індивідів або їхніх груп до самоствердження і підвищення суспільного статусу шляхом реалізації новаторських ідей, забезпечення високого комерційного ефекту підприємства та дотримання цілей сталого розвитку. Такий підхід підкреслює особливий характер підприємництва як одного з найбільш перспективних видів економічної діяльності в агарній сфері. 